2

\title{
Factorial design of experiment (DOE) for modeling solar still parameters
}

\author{
Malik Al-Abed Allah*', Mohammad Abu Abbas'Moath Maqableh \\ Department of Mechanical Engineering, Jordan University of Science and Technology, \\ Irbid, Jordan \\ *Correspondence: myalabedallah16@eng.just.edu.jo
}

Malik Al-Abed Allah, Department of Mechanical Engineering, Jordan University of Science and Technology, 22110, Irbid, Jordan, 00962780727675

myalabedallah16@eng.just.edu.jo

Mohammad Abu Abbas, Department of Mechanical Engineering, Jordan University of Science and Technology, 22110, Irbid, Jordan, 00962776752488/ moabuabbas16@eng.just.edu.jo

Moath Maqableh, Department of Mechanical Engineering, Jordan University of Science and Technology, 22110, Irbid, Jordan, 00962787594287/ mfmaqableh16@eng.just.edu.jo 
Key words: solar still, DOE, factorial design, fins, thickness, productivity, water depth, insulation.

\begin{abstract}
Water scarcity is a major threat to the future due to the fact that the pollution rate of freshwater resources is getting increased rapidly. At the same time, the level of water usage is dramatically increased. Hence, to fulfill the water demand, converting the brackish, saline water into pure water is one of the viable solutions. Desalination using solar still is a simple technique among various techniques available for salinity removal. Researchers have consistently attempted to improve the performance of solar stills due to poor productivity. This article highlights various factors that have an impact on the performance of the solar still such as solar radiation, basin area, saline water depth, insulation material, the thickness of glass cover, and wind speed. In order to achieve high performance via optimization of the effected parameters required for solar still, the design of experiments (DOE) can determine the most effective parameters and eliminate the least important ones. Moreover, solar still is often complex and time-consuming due to the various parameters that must be taken into consideration. Furthermore, this research focuses on reducing the computing time and determines the most significant parameters of the solar still, such as Basin area, saline water depth, and solar radiation. The theoretical results demonstrate that the most important factor that affects solar still productivity is basin area, saline water depth, and solar radiation respectively. While the insulation thermal conductivity, ambient temperature, and glass thickness have no effect on the performance of still.
\end{abstract}

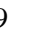
0 3 4 


\section{Introduction}

Lacking access to potable water is considered as one of the major issues for individuals who live in arid remote areas from all around the world. United Nations has named the twenty-second of March World Water Day of every year, with the 2017 theme of "Water Quality: Clean Water for a Healthy World." to draw the global attention to such crisis [1]. About 1.1 billion persons, globally, are deprived of clean freshwater [2]. Along with expensive fossil fuel, the deficiency of drinkable water becomes aggravated for these people. Solar Still technology came as one of the optimal suitable solutions for this problem, especially in areas where solar energy is abundant which coincides with the pretense of the deprived water communities [3].

Solar Stills can be placed at each house for producing at least potable water. They are economical and inexpensive, simple in design, and pollution-free. Yet, there is a serious challenge that is associated with solar still which is the relatively small amount of fresh water produced. The latter is affected by a set of factors that increase the temperature difference between saline water and glass cover inside solar still such as the amount of solar radiation, saline water depth inside still, basin area, insulation thickness, and many other parameters.

Khalifa and Hamood. (2009) studied the effect of insulation on the productivity of a basin type solar still. Solar stills with an insulation thickness of 30, 60, and $100 \mathrm{~mm}$ were examined, and the results were compared with those obtained for a still without insulation. they found that the insulation thickness has a significant impact on the productivity of the still up to a thickness of $60 \mathrm{~mm}$. Moreover, the insulation thickness could influence the productivity of the still by over $80 \%$. Al-Karaghouli and Alnaser. (2004) fabricated two solar-stills (single basin and double-decker) and tested at the campus of the University of Bahrain. Two types of measurements were conducted; one with still-sides insulation and the other without. They observed that the influence of side insulation is significant in water production, especially for the double-basin type by about $43.8 \%$ in June. Manokar et al. (2020) investigated experimentally the impact of water depth and insulation on the productivity of acrylic pyramid solar still, the results showed that the maximum yield from solar still without insulation at different depths of water namely 2,3 , and $3.5 \mathrm{~cm}$ were found to be $2.8,2.26$, and $1.67 \mathrm{~kg} / \mathrm{m}^{2}$ respectively. whereas, the effect of insulation improved the freshwater produced higher yield and recorded as $3.38,2.94,2.06 \mathrm{~kg} / \mathrm{m}^{2}$ respectively. Velmurugann et al. (2008) conducted an experimental study aimed to increase the distilled water productivity for the single basin solar still by increasing exposure area in different ways (still with sponges, wick type solar still, and still with fins at the basin). The results show that 
productivity increased $29.6 \%$ when wick type solar still was used, $15.3 \%$ productivity increased when sponges were used, and $45.5 \%$ increased when fins were used. Hachemi. (1999) investigated a new technique to enhance the heat transfer with fully developed turbulent flow. An experimental study showed that the generated enhancement of thermal performance. The offset rectangular plate fins mounted in a staggered pattern, were oriented parallel to the fluid flow and are soldered to the underside of the absorber plate. High thermal performances were obtained with low flow friction and in consequence a low electrical power consumption by the fan in comparison to the flat plate collector. El-Sebaii et al. (2015) examined the effect of fin arrangement on the solar still productivity. they inferred that the fin height was proportional to productivity while the fin thickness and fin number were inversely proportional to the performance. Nisrin Abdelal et al. (2017) conducted an experiment to study the effect of using absorber plates made of carbon fiber/nanomaterials- modified epoxy composites at different concentrations on pyramid solar still. Their experimental results showed that the productivity of still increases by $109 \%$ and $65 \%$ when adding $5 \%$ and $2.5 \%$ Nano weight concentrations respectively. Ghoneyem et al. (1997) used software to solve some of the Empirical equations to statement the dependency of the water output on the ambient temperature and solar radiation fallen on solar still cover. He concluded that the average daily output increase with increase of solar radiation. Omar et al. (2007) performed theoretical and experimental analysis on single inclination solar still based on a change of solar radiation intensity. They concluded that as the solar intensity increases, the productivity of water output increases due to an increase in the latent heat of water inside solar still. Emad A. Almuhanna et al. (2014) concluded that the Efficiency of solar stills increases as solar radiation intensity Increases. Sahoo et al. (2008) concluded that the efficiency of solar still increases $11 \%$, by increase the capacity of water in the solar basin from 10 to $20 \mathrm{~kg}$. Suneja et al. (1999) used numerical calculations on double basin solar still to analyses the effect of water depth on the water productivity and Concluded that an increase in water depth decreases the efficiency of the solar still. Rajamanickam et al. (2012) studied the effect of water depth on water productivity in the double slope (DS) solar still, they used different water depth at the same condition $0.01 \mathrm{~m}, 0.025 \mathrm{~m}, 0.05 \mathrm{~m}, 0.075 \mathrm{~m}$ and obtained a maximum distillate yield $\left(3.07 \mathrm{l} / \mathrm{m}^{2}\right)$ per day at minimum water depth $(0.01 \mathrm{~m})$. Sebaii et al. (2000) used Numerical calculations on typical summer and winter days to analyze the effect of wind speed on water yield. It was found that productivity still increases with the increase of wind speed up to a critical value beyond which the increase in wind speed becomes inefficient. Rahmani et al. (2018) carried out numerical and experimental study on the effect of wind velocity on condensation surface area of still in summer and winter conditions, the results show that the effect of wind speed was more effective for small condensation area. El-Sebaii et al. (2004) studied the effect of wind velocity on the daily water yield for passive and active solar distillation using some of the numerical calculations and concluded that the daily productivity 
increases when wind speed reaches to a typical velocity $(10 \mathrm{~m} / \mathrm{s}$ in summer and $8 \mathrm{~m} / \mathrm{s}$ in winter) beyond which the increase in wind speed becomes inefficient. Edeoja et al. (2015) studied the effect of using five glass cover thickness on solar still performance. Still 1 has one glass cover, still 2 has two glass covers, still 3 has two glass covers with airspace separate between each other's, still 4 has three glass covers without airspace, and still 5 has three glass covers with airspace separate between each one. The results showed that Still 1 has the highest water productivity, where it reached to about $306 \mathrm{~cm}^{3}$ and an efficiency about 24\%. Hitesh N Pancha et al. (2012) conducted three experiments to investigate the effect of different glass cover thicknesses on single slope solar still in winter conditions of Mehsana. The three thicknesses of glass cover are $0.004 \mathrm{~m}, 0.008 \mathrm{~m}$, and $0.012 \mathrm{~m}$. The experiment results showed that as increase glass cover thickness, the distillate water, and efficiency decrease. Abu Abbas \& Al-Abed Allah. (2020) investigated the effect of condenser materials type and condenser slope on the performance of the solar still numerically. five types of condenser materials were examined: PMMA, PET, PC, Glass, and PVC. Moreover, four slope angels for condenser were tested at different seasons: $5^{\circ}, 20^{\circ}, 35^{\circ}$, and $45^{\circ}$, the results revealed that the daily solar still productivity increases as transmissivity value of condenser material increase. Besides, it was noted that the maximum productivity in summer (May) was at the lowest condenser slope angle $\left(5^{\circ}\right)$ and it was decreased as the condenser slope angle increased. On the other hand, the maximum productivity of solar still in the winter season (January) was at $\left(20^{\circ}\right)$ and then decreased as the condenser slope angle increased.

As we described above the performance of solar still and its productivity depends mainly on increasing the temperature difference between saline water and glass cover. A lot of parameters studied by a different researcher to improve the temperature difference such as solar radiation intensity, ambient Temperature, depth of saline water, bottom and side insulation thickness, basin area, bottom and side insulation material and wind speed. The parameters like solar insolation intensity and wind speed are uncontrolled because they depend on environmental conditions. While other parameters such as basin water depth, basin area, insulation, etc. are Controllable parameters and can be improved effectively to increasing productivity of still. In this research, design of the experiment (DOE) is used to show the most significant parameters, insignificant parameters, and the interaction between parameters that affect three responses: distilled water, saline water temperature, and glass cover temperature. Moreover, regression equations for all responses have been illustrated.

\section{Methodology:}

\subsection{Design of Experiment:}

Design of Experiment is a tool for designers and experts to use for product design and development, this tool can reduce development lead time and cost, leading to processes or simulations, and has high reliability than other approaches. The main objective of the experiment is to determine which variables are most influential on the response. even you can set the influential factors that affect the system performance near the desired value with its variety and neglect the effects of fewer influence factors. The equation (1) resulting from statistical regression analysis. 
Here, $f(x)$ is the predicted response variable, and $a_{o}, a_{i}, a_{i i}$ and $a_{i, j}$ are the regression

$$
f(x)=a_{o}+\sum_{i=1}^{k} a_{i} x_{i}+\sum_{i=1}^{k} a_{i, i} x_{i}{ }^{2}+\sum_{i=1}^{k-1} \sum_{j=i+1}^{k} a_{i, j} x_{i} x_{j}+\varepsilon
$$
coefficients of the intercept, linear, quadratic and interaction effects, respectively, while $\mathrm{x}_{\mathrm{i}}$ and $\mathrm{x}_{\mathrm{j}}$ are independent input variables, and $\varepsilon$ is a random error.

In this study a reduced factorial design had used to investigate the significance of nine factors that are mostly concerned with solar desalination systems. Three responses had analyzed which are distilled water, Water temperature, and glass cover temperature. A $2^{\wedge}$ ${ }^{(9-2)}$ Reduced factorial had used in order to specify the most significant factors of the nine factors of interest, determine their interactions and regression equations for all responses. proposed solar still is given in Figure 1. 


\subsection{Factorial Design:}

A factorial design is an important type of design of experiments approaches, which is essentially used to find the most significant factors to perform your investigation on them, instead of performing it on a full scale. As a result of this, the researchers could save tremendous effort and time. Furthermore, it would be more cost-effective because the number of experimental trials would much less than performing a full-scale experiment. In addition, the most important advantage of the factorial design is to determine the interactions between the factors of interest which would be impossible to determine in the regular analysis. In order to achieve all the previous advantages the factorial design method can set different values for each factor (levels), these levels and their ranges and values could be specified by experience, then the researchers have to generate a runs table by using probability counting rule $\left(2^{\wedge} \mathrm{k}\right)$ where: $\mathrm{k}$ is the number of factors. As shown in table (1).

\subsection{Reduced Factorial $2^{\wedge}(9-2)$ :}

This investigation has 9 factors of interest and tremendous effort would be consumed, if a full factorial design had been performed. As a result of this we performed reduced factorial, the main idea in reduced factorial design that the design had performed with much less trials by sacrificing interactions for more than three factors which are not of our interest in this step. On the other hand, reduced factors had been chosen very carefully by checking the alias structure, resolution, balancing and orthogonally. In this study a $2^{\wedge(9-2)}$ reduced factorial had performed with IV resolution, which means No main effects are aliased with any other main effect or 2-factor interactions, but some 2-factor interactions are aliased with other 2-factor interactions and main effects are aliased with 3-factor interactions. In this step we concerned with the significance of the main effects which mentioned above. Matlab program has been used to simulate the three responses and Minitab software for DOE. 


\section{4 simulation assessment}

The flowchart corresponding to the applied method in this study is shown in Figure 2. The simulation starts with a select type of analysis, the number of factors and nature of runs (randomity or non-randomity) using Minitab, after that the unknown temperatures $\mathrm{T}_{\mathrm{g}}, \mathrm{T}_{\mathrm{w}}$, $\mathrm{T}_{\mathrm{b}}$, and the distilled water are obtained by solving the differential equations for solar still using Matlab software, The best method for solving the system of equations is Runge-Kutta fourth-order method. The values of $T_{g}, T_{w}, T_{b}$, and distilled water were calculated for one hour.

\section{Results:}

The chosen mathematical formula and numerical procedure could determine the amount of freshwater, water temperature, and glass cover temperature for a given conditions. Hence, solar radiation intensity, basin area, water depth, insulation material, insulation's thickness, glass cover's thickness, wind velocity, and ambient temperature are considered as variables to understand their effects on the freshwater production. To be more efficient, test conditions are designed based on the methodology of design of experiment (DOE). The design of experiment (DOE) is performed on $2^{\wedge} \mathrm{k}$ parameters at two levels to understand their direct effects and also their interactions (indirect effect) on the desired responses.

\subsection{Main Effect Plots Results}

Figure $3 \mathrm{a}, \mathrm{b}$ and c illustrate the main factors which affected the responses of the solar desalination system. It has been observed that there is a proportional relationship between the slope of line and the effect of the parameters on the responses. Figure 3.a demonstrates that the most significant factors to increase the amount of distilled water are water depth, basin area, and solar radiation respectively. in contrast, glass thickness, ambient temperature, and insulation material do not have any effect on the system. Figure 3.b shows that water depth and solar radiation are the main factors affected the water temperature of the solar desalination system. While the other factors have a neglectable impact to increase the water temperature. Furthermore, the simulation concluded that the main factors affected on the glass cover's temperature are water depth, solar radiation, and wind speed respectively as shown in Figure 3.c. The designers should select high-level values for factors that increase water temperature and low-level values for factors that decrease glass cover's temperature to get the maximum level of distillation. 


\subsection{Normal Plots of the Standardized Effects' Results}

The obtained results from the simulation illustrates all the influenced and non-influenced factors that affected all responses. Figure 4.a, b, and c show normal plots of the standardized effect for distilled water, water temperature, and glass temperature respectively. Furthermore, it illustrates the interactions between factors for each response. In Figure 4.a, it is clearly observed that the highly weighted factors which play a key role in producing highly distilled water are basin area, solar radiation, and interaction between them respectively, on the high-level values of the studied parameters. On the other hand, at lowlevel values, the major factors that improve the distilled water productivity are water depth, the interaction between water depth and basin area in addition to the interaction between water depth and solar radiation, respectively. As shown in Figure 4.b the main parameters affected the water temperature at high-level values are solar radiation, the interaction between wind speed and water depth, and insulation thickness. While at the low-level values, the most significant factors that increase water temperature are water depth and interaction of solar radiation with water depth respectively. additionally, Figure 4.c indicates that the most influential factors at high-level values are the interaction of wind speed with water depth, solar radiation, and insulation thickness respectively. While at lowlevel values are water depth and wind speed respectively. 


\subsection{Regression Equations}

Regression has been performed on the obtained data, results, of factorial in order to reveal the effects of these parameters on the freshwater production. Eq.2, 3 and 4 are the regression functions estimated from DOE analysis of $2^{\wedge k}$ factorial model to predict three responses: distilled water, water temperature and glass cover temperature respectively. The constants refer to the affected coefficient of each factor while the plus and minus signals refer to the high or low level of the factors.

Distillated Water $=-489-14$ A- 232 B- 225 C- $0.140 \mathrm{D}-40 \mathrm{E}-3.5 \mathrm{~F}+1.6 \mathrm{G}+14 \mathrm{H}+$ 202.6 J- 0.8 A*B+ 7.10 A*C+0.0126 A*D+12 A*E+0.013 A*F+0.033 A*G+0.13 A*H - $1.832 \mathrm{~A}^{*} \mathrm{~J}-4 \mathrm{~B}^{*} \mathrm{C}+0.006 \mathrm{~B}^{*} \mathrm{D}+158 \mathrm{~B}^{*} \mathrm{E}+0.2 \mathrm{~B} * \mathrm{~F}+0.6 \mathrm{~B}^{*} \mathrm{G}+7 \mathrm{~B}^{*} \mathrm{H}+4.4 \mathrm{~B}^{*} \mathrm{~J}$ (2)

Water temperature $=33.5-1.03 \mathrm{~A}+68 \mathrm{~B}+4.96 \mathrm{C}+0.0088 \mathrm{D}+0.1 \mathrm{E}-0.309 \mathrm{~F}+0.227$ G- $1.83 \mathrm{H}-0.12 \mathrm{~J}+1.43 \mathrm{~A} * \mathrm{~B}+0.097 \mathrm{~A} * \mathrm{C}-0.000082 \mathrm{~A} * \mathrm{D}+1.76 \mathrm{~A} * \mathrm{E}-0.01264 \mathrm{~A} * \mathrm{~F}+$ $0.00455 \mathrm{~A} * \mathrm{G}-0.0325 \mathrm{~A} * \mathrm{H}-0.0567 \mathrm{~A} * \mathrm{~J}-4.01 \mathrm{~B} * \mathrm{C}+0.0101 \mathrm{~B} * \mathrm{D}-98 \mathrm{~B} * \mathrm{E}+0.318 \mathrm{~B} * \mathrm{~F}-$ $0.197 \mathrm{~B} * \mathrm{G}+1.79 \mathrm{~B} * \mathrm{H}+0.800 \mathrm{~B} * \mathrm{~J}$

Glass temperature $=12.9+0.18 \mathrm{~A}-1.7 \mathrm{~B}+0.46 \mathrm{C}+0.0181 \mathrm{D}+15.2 \mathrm{E}+0.150 \mathrm{~F}+0.007$ G- $0.11 \mathrm{H}+0.93 \mathrm{~J}+0.06 \mathrm{~A} * \mathrm{~B}+0.0096 \mathrm{~A} * \mathrm{C}+0.000181 \mathrm{~A} * \mathrm{D}+0.08 \mathrm{~A} * \mathrm{E}-0.00954 \mathrm{~A} * \mathrm{~F}+$ $0.00020 \mathrm{~A}^{*} \mathrm{G}-0.0038 \mathrm{~A} * \mathrm{H}-0.0323 \mathrm{~A} * \mathrm{~J}+0.20 \mathrm{~B} * \mathrm{C}-0.0004 \mathrm{~B} * \mathrm{D}+1 \mathrm{~B} * \mathrm{E}-0.012 \mathrm{~B} * \mathrm{~F}+$ $0.012 \mathrm{~B} * \mathrm{G}+0.03 \mathrm{~B} * \mathrm{H}+0.043 \mathrm{~B} * \mathrm{~J}+0.000111 \mathrm{C} * \mathrm{D}$ 


\subsection{Contour and surface curves}

The contour and surface plots are master tools to describe the effect of each parameter simultaneously rather than calculating one by one via the simulation code. These pros can be clearly observed in Figures 5, 6, and 7 represent the effects of some parameters on the production of freshwater. Figure 5 represents the effect of water depth and solar radiation on the freshwater's production for a given conditions (A-J). It is shown that the distilled water production is improved when water depth is decreased, and solar radiation is increased. Figure 6 represent another contour that illustrates the effect of water depth and basin area on the freshwater production. As seen, for a given aforementioned parameters (A-J), decreasing the water depth and increasing basin area could play a role in increasing the amount of distilled water. Interesting information is found in Figure 7; the effects of basin area and solar radiation on the distilled water production. As seen, for given conditions (A-J), as increasing basin area and solar radiation the productivity of distilled water increases. These kinds of contours could be drawn for different considered parameters in order to find suitable conditions for the system. 


\section{Conclusion}

The DOE methodology has attracted the scientists for a wide range of industrial applications such as Pharmaceutical, biotechnology...etc. There is plethora of advantages of DOE as it provides a rapid evaluation of the effects of different parameters or important factors on the selected response variables and their possible interactions. Thus, factors can be simultaneously changed and optimized. DOE approach enables the study of a large number of parameters as the case of the solar desalination system and the feasibility to operate as a promising and efficient optimization technique. In this study a new methodology of solar desalination system performance evaluation and tool could be developed based on parametric design, to determine the most important factors influenced on distilled water, water temperature and glass temperature. Plots of this curves provides the ability to select the factors (e.g basin area, wind speed, water depth, insulation material and thickness...ect) quickly and accurately according to the required performance of the designers. The developed model has simple form and can calculate rapidly the responses, which allows to study different factors for all solar desalination system design. Moreover, the design of the experiments reduces significantly the number of dynamic simulations required to determine the coefficients of the parametric models.

\section{Conflict of Interest}

The authors declare that they have no conflict of interest. 


\section{References:}

[1] Weerasekara, Permani. "The United Nations World Water Development Report 2017 Wastewater." Future of Food: Journal on Food, Agriculture and Society 5.2 (2017): 80-81.

[2] World Health Organization. "Progress on drinking water, sanitation and hygiene: 2017 update and SDG baselines." (2017).

[3] Mohamed, Mona B. "Low cost nanomaterials for water desalination and purification." Final Technical Report. United Nations UNSCO, 2011.

[4] Khalifa, Abdul Jabbar N., and Ahmad M. Hamood. "Effect of insulation thickness on the productivity of basin type solar stills: an experimental verification under local climate." Energy Conversion and Management 50.9 (2009): 2457-2461. https://doi.org/10.1016/j.enconman.2009.06.007

[5] Al-Karaghouli, A. A., and W. E. Alnaser. "Experimental comparative study of the performances of single and double basin solar-stills." Applied Energy 77.3 (2004): 317-325. https://doi.org/10.1016/S03062619(03)00124-7

[6] Manokar, A. Muthu, et al. "Effect of water depth and insulation on the productivity of an acrylic pyramid solar still-an experimental study." Groundwater for Sustainable Development 10 (2020): 100319. https://doi.org/10.1016/j.gsd.2019.100319

[7] Velmurugan, V., et al. "Single basin solar still with fin for enhancing productivity." Energy Conversion and Management 49.10 (2008): 2602-2608. https://doi.org/10.1016/j.enconman.2008.05.010

[8] Hachemi, A. "Experimental study of thermal performance of offset rectangular plate fin absorberplates." Renewable Energy 17.3 (1999): 371-384. https://doi.org/10.1016/S0960-1481(98)00115-3

[9] El-Sebaii, A. A., et al. "Effect of fin configuration parameters on single basin solar still performance." Desalination 365 (2015): 15-24. https://doi.org/10.1016/j.desal.2015.02.002

[10] Abdelal, Nisrin, and Yazan Taamneh. "Enhancement of pyramid solar still productivity using absorber plates made of carbon fiber/CNT-modified epoxy composites." Desalination 419 (2017): 117124. https://doi.org/10.1016/j.desal.2017.06.012

[11] Ghoneyem, Abdulrahman, and Arif Ileri. "Software to analyze solar stills and an experimental study on the effects of the cover." Desalination 114.1 (1997): 37-44. https://doi.org/10.1016/S00119164(97)00152-5

[12] Badran, Omar O., and Mazen M. Abu-Khader. "Evaluating thermal performance of a single slope

solar still." Heat and mass transfer 43.10 (2007): 985-995. https://doi.org/10.1007/s00231-006-0180-0

[13] Emad A. Almuhanna, Evaluation of single slop solar still integrated with evaporative cooling 
[14] Sahoo, B. B., et al. "Performance assessment of a solar still using blackened surface and thermocol insulation." Renewable energy 33.7 (2008): 1703-1708. https://doi.org/10.1016/j.renene.2007.09.009

[15] Suneja, Sangeeta, and G. N. Tiwari. "Effect of water depth on the performance of an inverted absorber double basin solar still." Energy Conversion and Management 40.17 (1999): 1885-1897. https://doi.org/10.1016/S0196-8904(99)00047-3

[16] Rajamanickam, M. R., and A. Ragupathy. "Influence of water depth on internal heat and mass transfer in a double slope solar still." Energy procedia 14 (2012): 1701-1708. https://doi.org/10.1016/j.egypro.2011.12.1155 .

[17] El-Sebaii, A. A. "Effect of wind speed on some designs of solar stills." Energy Conversion and Management 41.6 (2000): 523-538. https://doi.org/10.1016/S0196-8904(99)00119-3

[18] Rahmani, Ahmed, and Abdelouahab Boutriaa. "Numerical and experimental study of a passive solar still integrated with an external condenser." International Journal of Hydrogen Energy 42.48 (2017): 29047-29055. https://doi.org/10.1016/j.ijhydene.2017.07.242

[19] El-Sebaii, A. A. "Effect of wind speed on active and passive solar stills." Energy Conversion and Management 45.7-8 (2004): 1187-1204. https://doi.org/10.1016/j.enconman.2003.09.036

[20] Edeoja, Alex Okibe, Fadoo Unom, and Joy Acheyini Edeoja. "Investigation of the Effect of Cover Thickness on the Yield of a Single Basin Solar Still under Makurdi Climate." International Journal of Engineering Science Invention ISSN (Online) (2015): 2319-6734.

[21] Panchal, Hitesh N., and Pravin Shah. "Effect of Varying Glass cover thickness on Performance of Solar still: in a Winter Climate Conditions." International Journal of Renewable Energy Research 1.4 (2012): 212-223.

[22] Mohammad Omar Abu Abbas, Malik Yousef Al-Abed Allah "Effect of Condenser Materials Type and Condenser Slope on the Performance of Solar Still" Published in International Journal of Trend in Research and Development (IJTRD), ISSN: 2394-

9333, Volume-7 | Issue-2 , April 2020, URL:




\section{List of figures}

486

Figure 1. A schematic view of the proposed single slope solar still.

Figure 2. Simulation steps using Minitab and Matlab softwares.

Figure 3. main effect plots for (a) distilled water, (b) water temperature and (c) glass cover temperature.

Figure 4. Normal plots of the standardized effects for (a) distilled water (b) water temperature and (c)

491 glass cover temperature.

492 Figure 5. Contour and surface curves of solar radiation and water depth on distilled water.

Figure 6. Contour and surface curves of basin area and water depth on distilled water

494 Figure 7. Contour and surface curves of solar radiation and basin area on distilled water

\section{List of Tables}

Table 1: Description of factor levels 


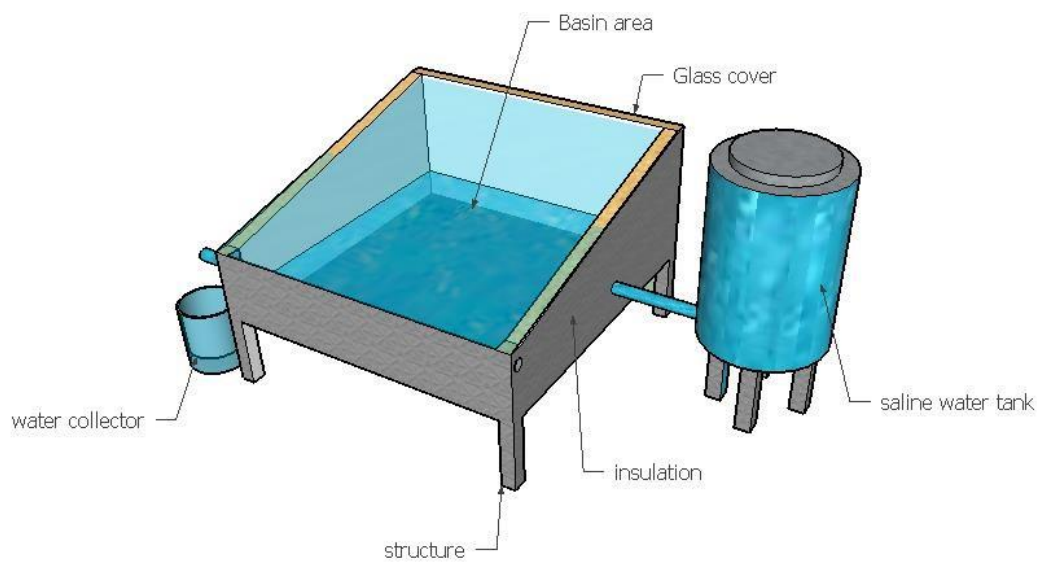

Figure 1: A schematic view of the proposed single slope solar still.

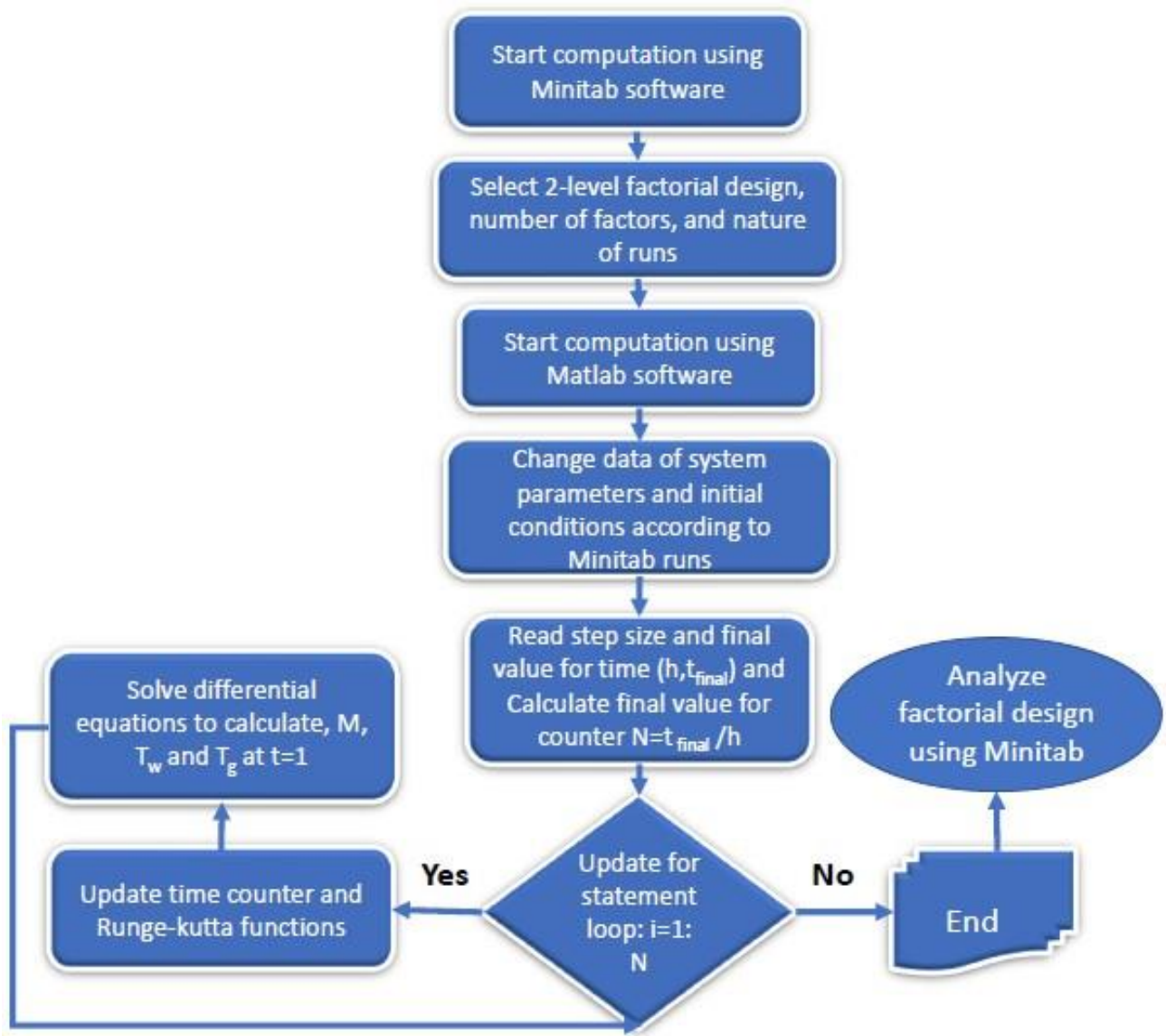

Figure 2: Simulation steps using Minitab and Matlab softwares. 
https://doi.org/10.5194/dwes-2020-28

Preprint. Discussion started: 9 September 2020

(c) Author(s) 2020. CC BY 4.0 License.

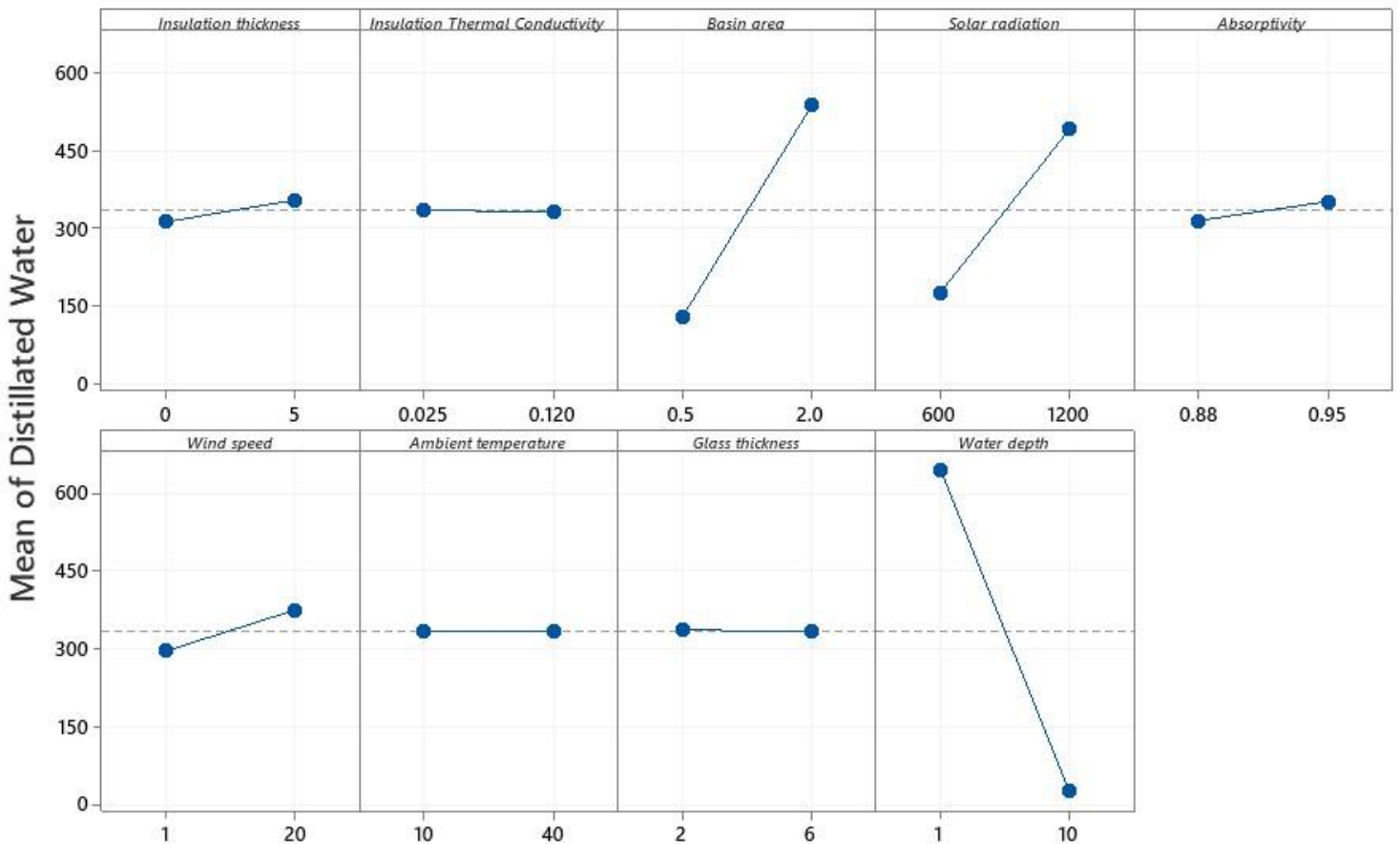

571 (a)

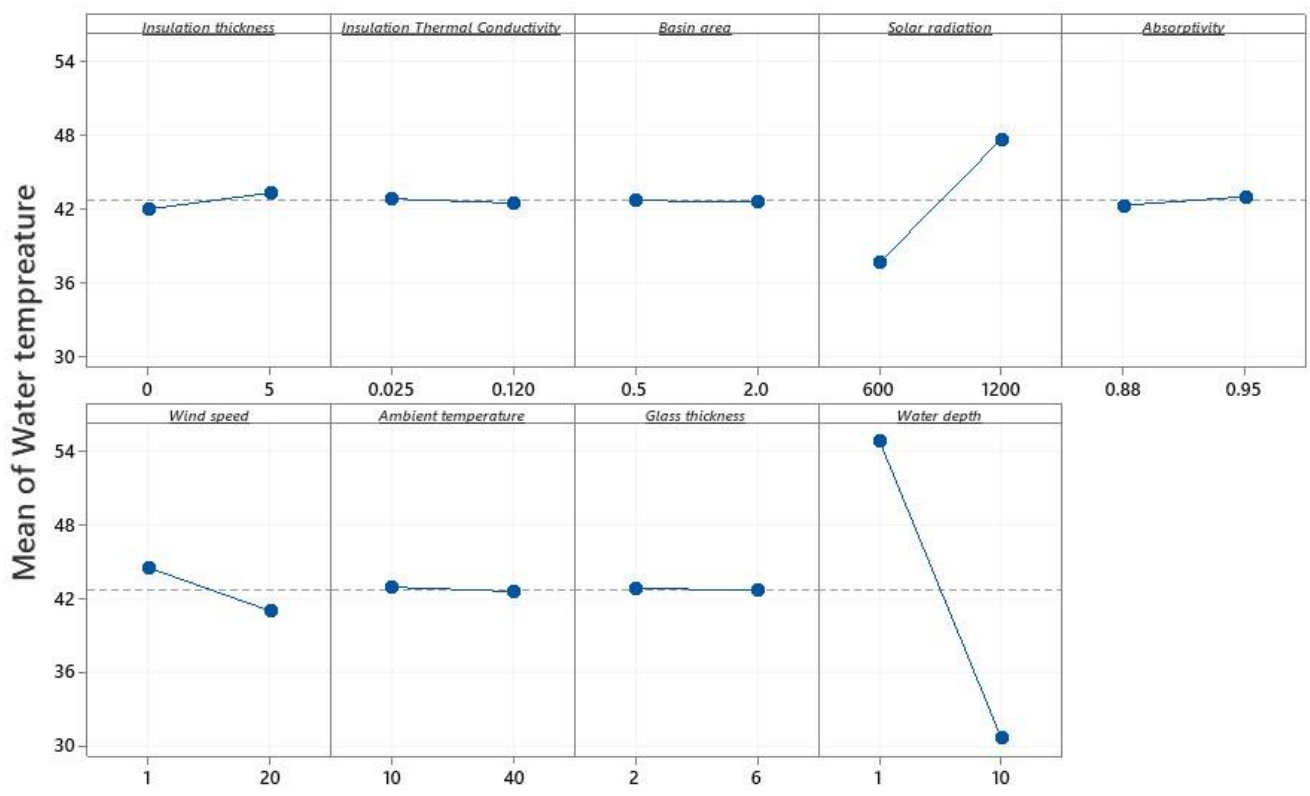

(b) 
https://doi.org/10.5194/dwes-2020-28

Preprint. Discussion started: 9 September 2020

(c) Author(s) 2020. CC BY 4.0 License.

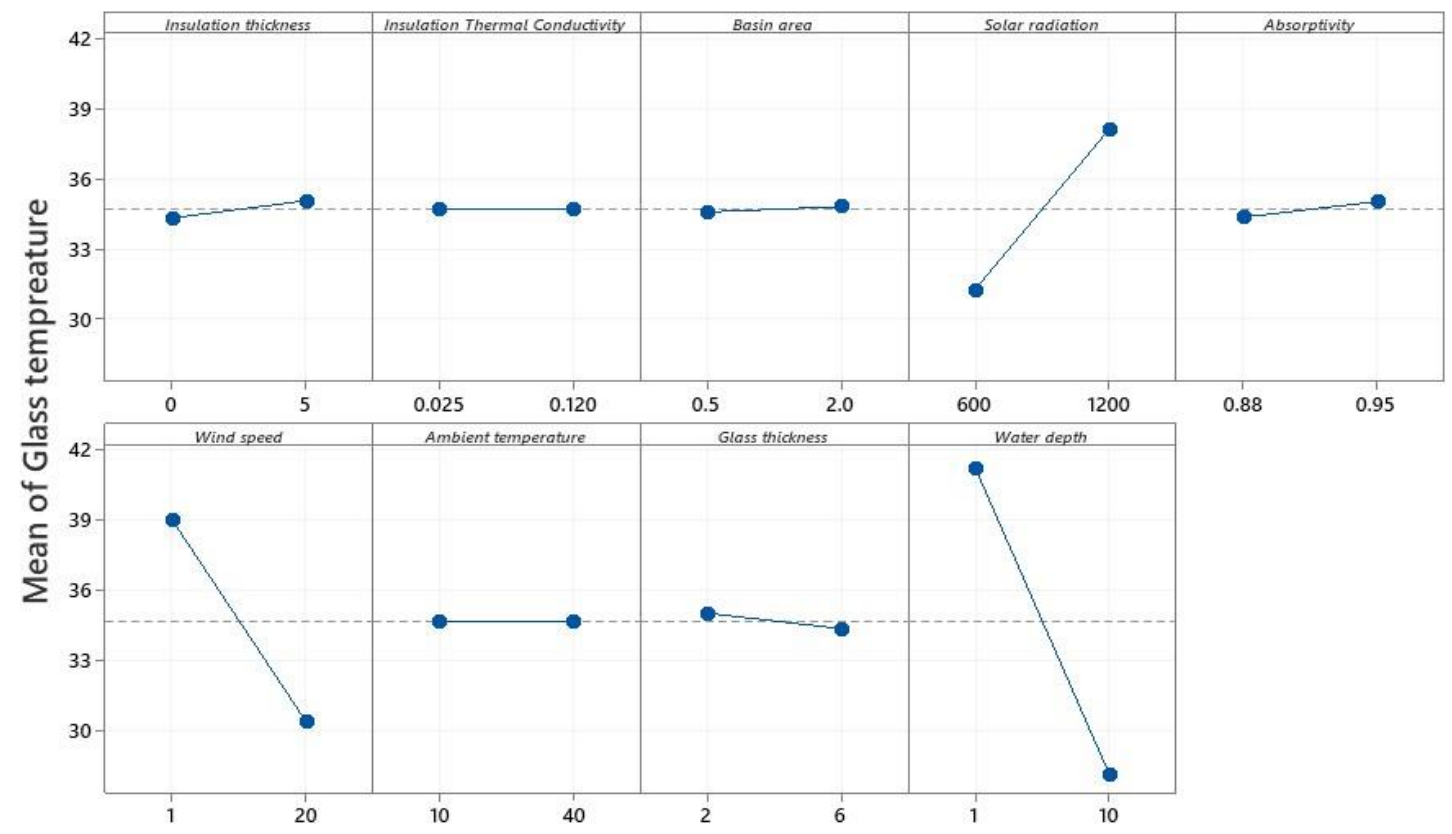

(c)

Figure 3: main effect plots for (a) distilled water, (b) water temperature and (c) glass cover temperature.

578

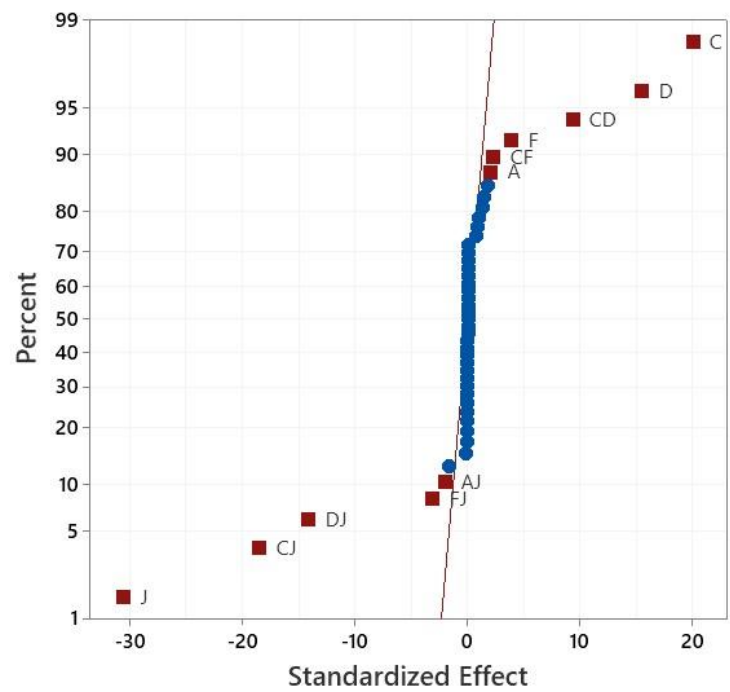

Effect Type

- Not Significan

- Significant

Factor Name

A Insulation thickness

B Insulation Thermal Conductivity

Basin area

Solar radiation

Absorptivity

Wind speed

Ambient temperature

Glass thickness

Water depth 
https://doi.org/10.5194/dwes-2020-28

Preprint. Discussion started: 9 September 2020

(c) Author(s) 2020. CC BY 4.0 License.
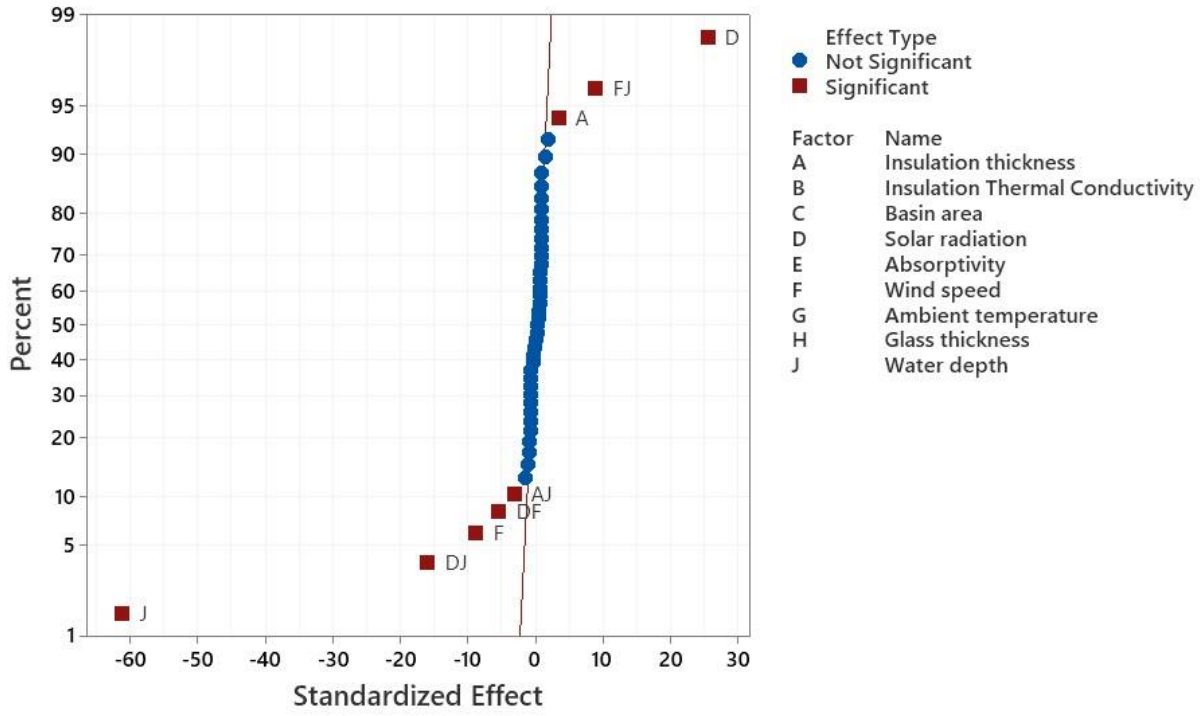

(b)

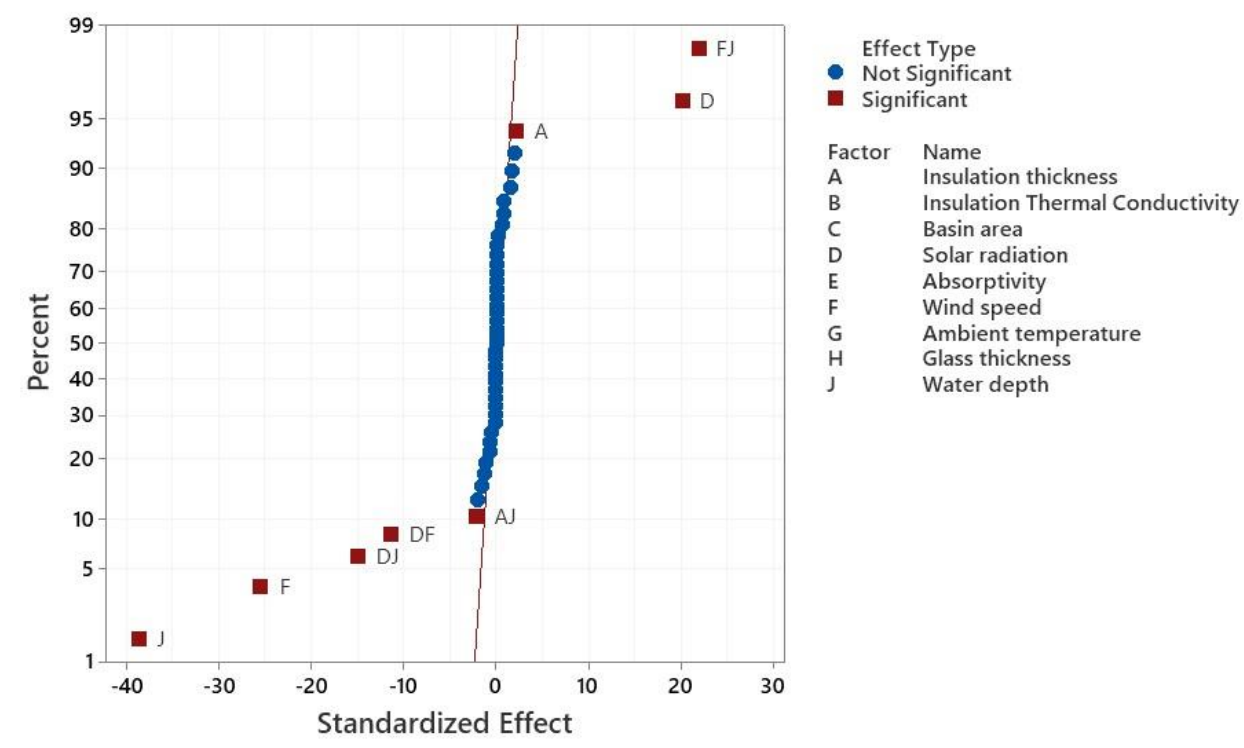

(c)

Figure 4: Normal plots of the standardized effects for (a) distilled water (b) water temperature and (c) glass cover temperature 


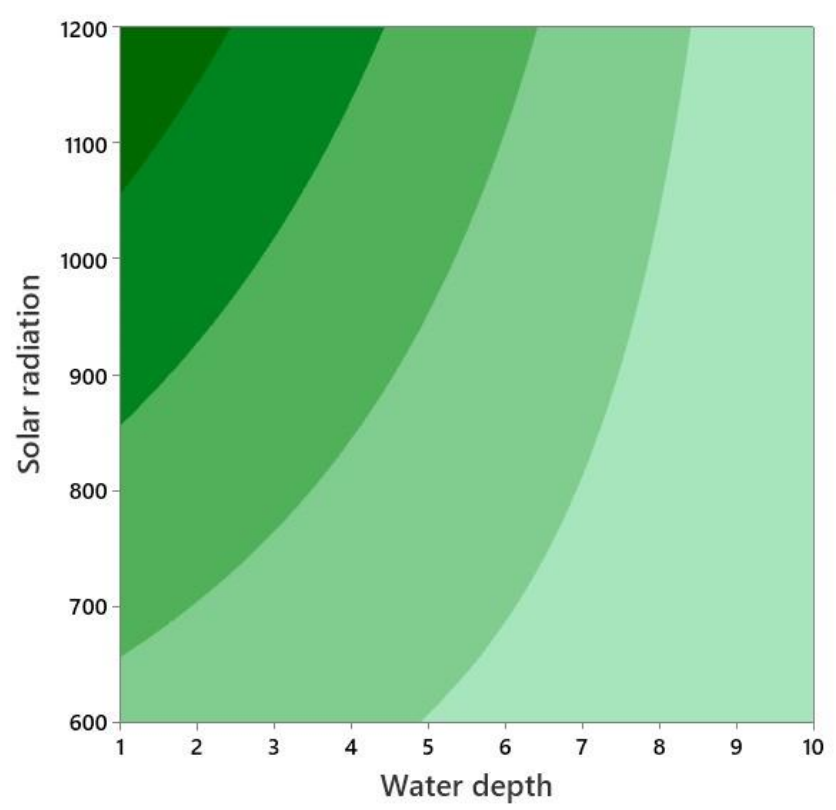

(a)

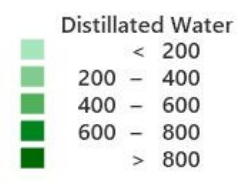

$$
\text { Hold Values }
$$

Insulation thickness

Basin area

Absorptivity

Wind speed

Ambient temperature

Glass thickness

\section{Hold Values}

Insulation thickness

Insulation Thermal Conductivity $\mathbf{0 . 0 7 2 5}$

Basin area

1.25

Absorptivity

0.915

Wind speed

10.5

Ambient temperature

Glass thickness

Water depth

Figure 5: Contour and surface curves of solar radiation and water depth on distilled water 
https://doi.org/10.5194/dwes-2020-28

Preprint. Discussion started: 9 September 2020

(c) Author(s) 2020. CC BY 4.0 License.

627

628

629

630

631

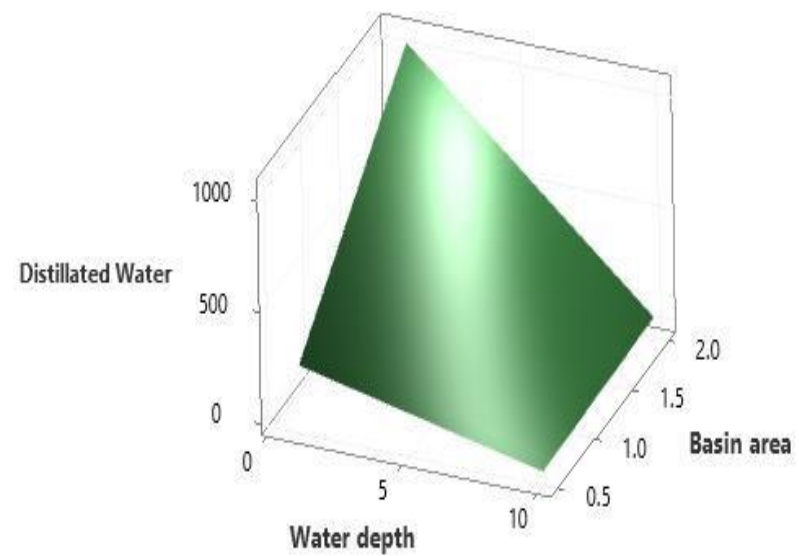

(a)

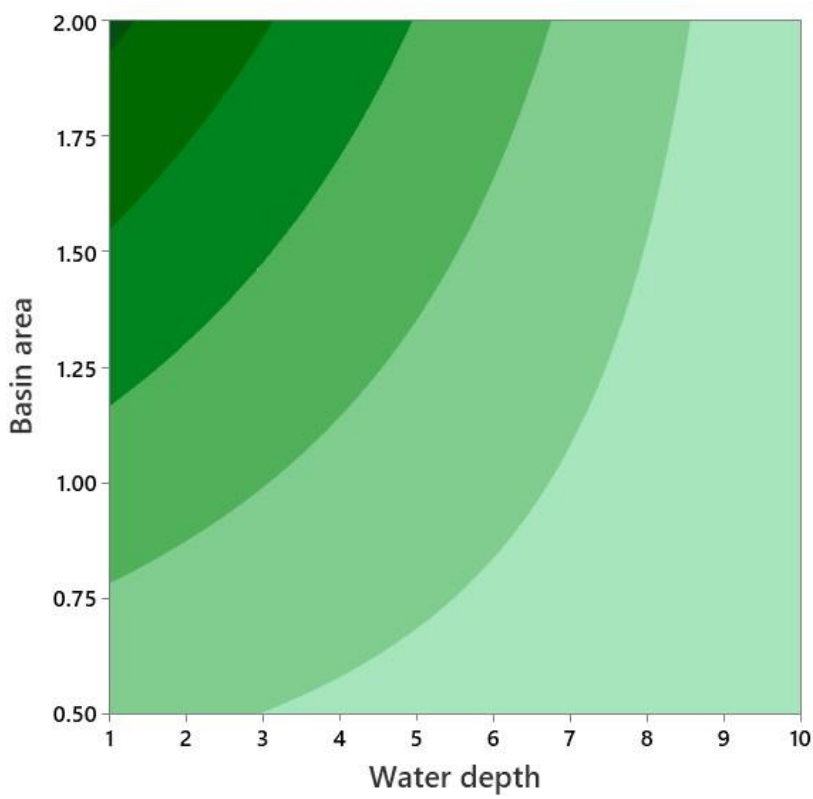

Distillated Water

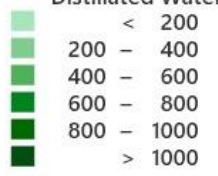

Hold Values

Insulation thickness

Insulation Thermal Conductivity 0.0725

Solar radiation

Absorptivity

Wind speed

Ambient temperature

Glass thickness

2.5
25
900
915
10.5
25
4

\begin{tabular}{lr}
\multicolumn{2}{c}{ Hold Values } \\
Insulation thickness & 2.5 \\
Insulation Thermal Conductivity & 0.0725 \\
Solar radiation & 900 \\
Absorptivity & 0.915 \\
Wind speed & 10.5 \\
Ambient temperature & 25 \\
Glass thickness & 4
\end{tabular}

Figure 6: Contour and surface curves of basin area and water depth on distilled water 
641

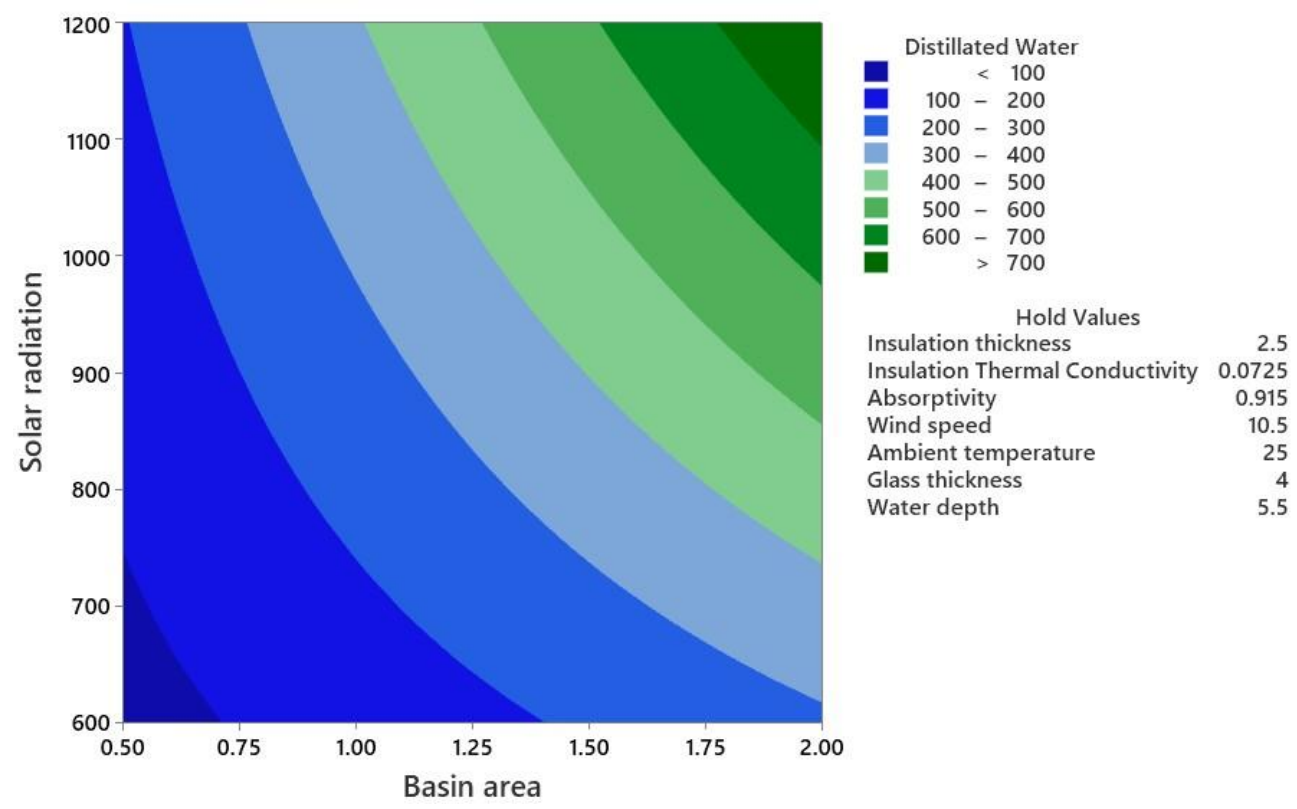

642

643

644

645

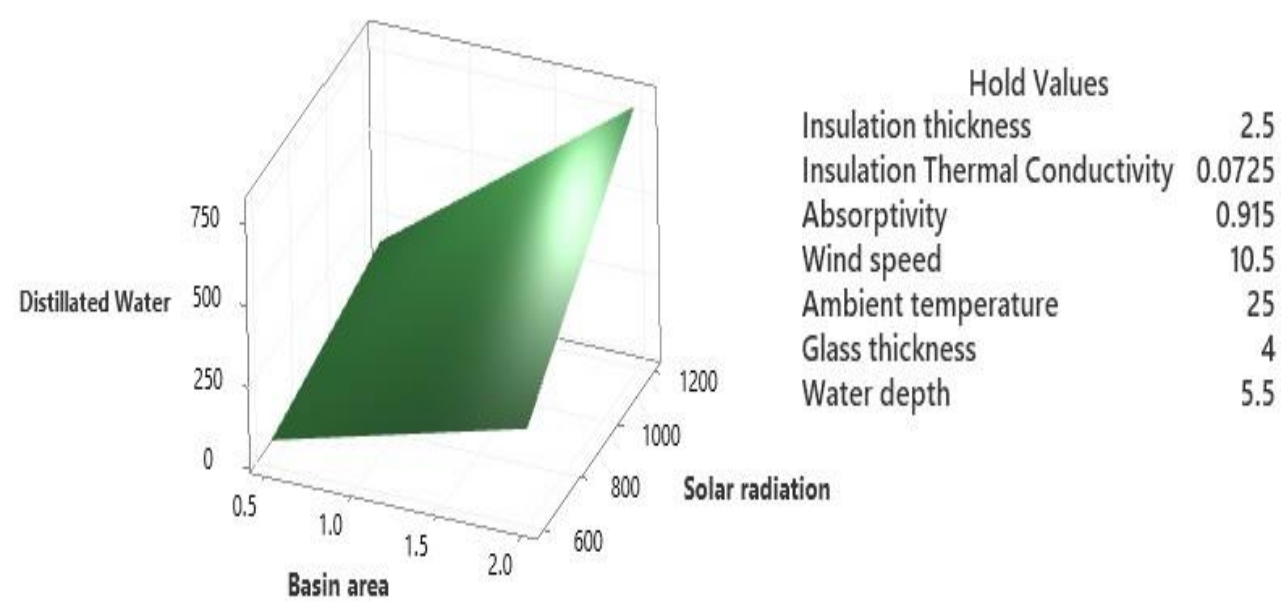

646

647

648

649

650

651 (b)

Figure 7: Contour and surface curves of solar radiation and basin area on distilled water 
https://doi.org/10.5194/dwes-2020-28

Preprint. Discussion started: 9 September 2020

(c) Author(s) 2020. CC BY 4.0 License.

653

654

655

656

657

658

659

660

661

662

663

664

665

666

667

668

669

670

671

672

673

Table 1: Description of factor levels

\begin{tabular}{llccc}
\hline Symbol & Factor Name & Low Level & High Level & Unit \\
\hline A & Insulation Thickness & 0 & 5 & $\mathrm{~mm}$ \\
B & $\begin{array}{l}\text { Insulation Thermal } \\
\text { Conductivity }\end{array}$ & 0.025 & 0.12 & $\mathrm{~W} / \mathrm{m} . \mathrm{C}^{\circ}$ \\
& Basin Area & 0.5 & 2 & \\
C & Solar Radiation & 600 & 1200 & $\mathrm{~W} / \mathrm{m}^{2}$ \\
D & Absorptivity & 0.88 & 0.95 & Unitless \\
E & Wind Speed & 1 & 20 & $\mathrm{~m} / \mathrm{s}$ \\
F & Ambient Temperature & 10 & 40 & $\mathrm{C}$ \\
G & Glass Thickness & 2 & 6 & $\mathrm{~mm}$ \\
H & Water Depth & 1 & 10 & $\mathrm{~cm}$ \\
\hline
\end{tabular}

